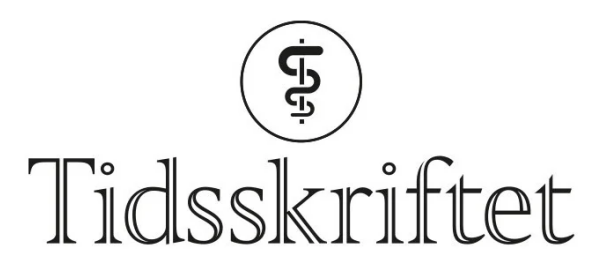

DEN NORSKE LEGEFORENING

\title{
Hvordan hjelpe barn med selektiv mutisme
}

ANMELDELSER

\section{HANNE KRISTENSEN}

Regionsenteret for barn og unges psykiske helse Helse $S \emptyset \mathrm{r}-\emptyset$ st

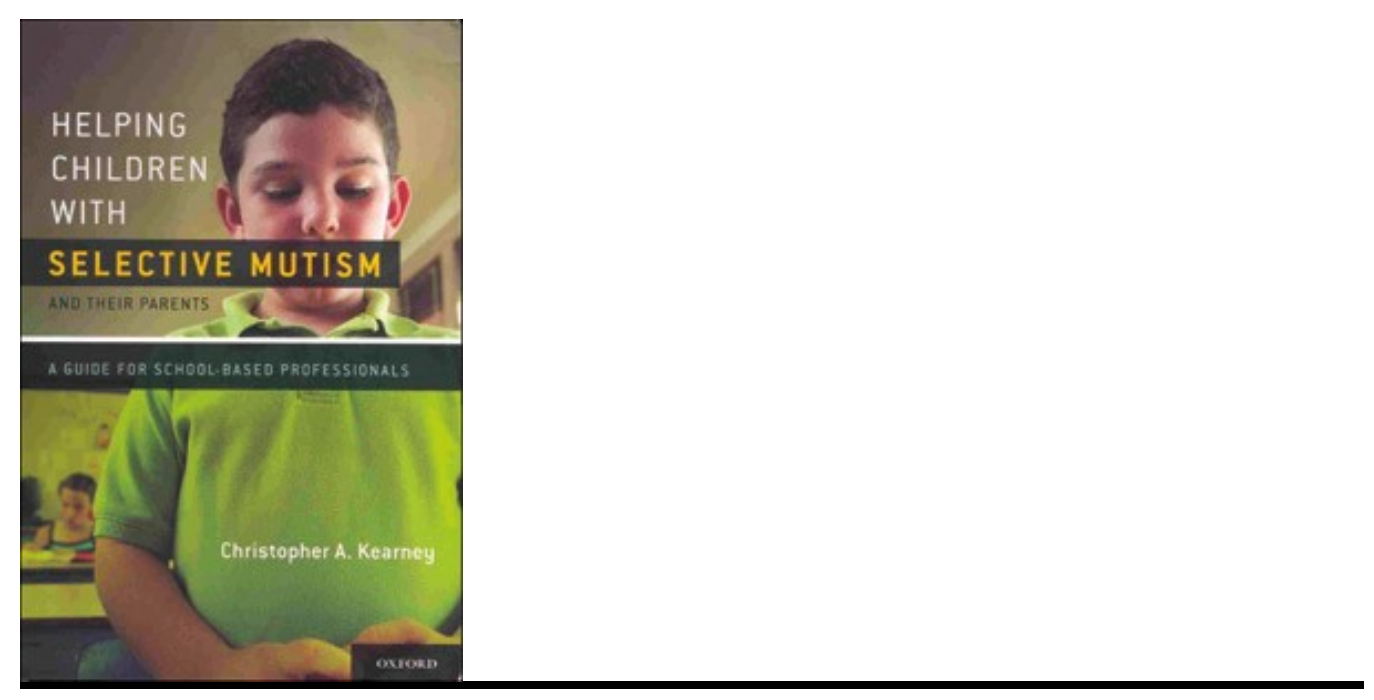

Kearney, Christopher A.

Helping children with selective mutism and their parents

A guide for school-based professionals. 149 s, ill. Oxford: Oxford University Press, 2010. Pris GBP 16

ISBN 978-0-19-539454-2

Boken omhandler barn med selektiv mutisme med hovedfokus på tiltak. Den er først og fremst rettet mot fagfolk som møter disse barna i en skolesammenheng, dvs. psykologer og pedagoger i pedagogisk-psykologisk tjeneste (PPT), helsesøstre, lærere og sosiallærere, men den anbefales også til andre profesjoner som ansatte i barne- og ungdomspsykiatriske poliklinikker (BUP), barneleger, fastleger og kommunepsykologer. 
Selektiv mutisme beskriver barn som konsekvent ikke snakker i visse situasjoner, slik som i barnehagen eller på skolen, mens de bruker språket i andre situasjoner, f.eks. hjemme. Tilstanden forstås som et uttrykk for stor grad av sosial angst, og forekomsten er ca. $1 \%$. Fagfolk får lite erfaring med tilstanden, og forskningsbasert empirisk kunnskap er sparsom. Foreldre risikerer derfor å bli møtt med manglende forståelse og virkningsløse tiltak når de oppsøker hjelpeapparatet.

I de sju kapitlene gis det et viktig bidrag til å øke kunnskapen om selektiv mutisme. Første kapittel beskriver tilstanden, kapittel to omhandler utredning og de fem neste behandling. Boken er lettlest og inneholder gode kasuistikker. Det første kapitlet er etter min mening det svakeste ettersom diagnostikk, etiologiske faktorer og prognose blir for summarisk beskrevet. Kjennskap til disse aspektene er også viktig for behandlingsvalg. For eksempel blir barn med selektiv mutisme og opposisjonell atferd sidestilt som undergruppe med tause barn med selektiv mutisme og sosial angst. Flere studier indikerer imidlertid at utagerende atferd hos disse barna er knyttet til den sosiale angsten. Dette er viktig å vite da manglende gjensvar fra et barn virker sterkt provoserende på en del voksne, og særlig hvis de tror at barnet kontrollerer tausheten.

De fem kapitlene som omhandler tiltak, er klart bokens styrke. Det beskrives konkret, praktisk og detaljert hvordan man bør gå frem for å hjelpe et barn med selektiv mutisme. Behandlingstilnærmingene består primært av forskjellige former for atferdsteknikker som får barnet gradvis til å tore å bruke tale. Forfatteren understreker viktigheten av å lage et angsthierarki sammen med barnet og å begynne med å øve i situasjoner med moderat angst. Øvingen skjer i reelle situasjoner sammen med behandler. Det understrekes også at behandlingen kan ta tid, og at det ikke finnes lettvinte løsninger.

For norske lesere er det et stort problem at fremstillingen så tydelig er myntet på et amerikansk behandlingsapparat. I Norge vil et barn med selektiv mutisme vanligvis først komme i kontakt med pedagogisk-psykologisk tjeneste. Denne tjenesten kan utrede, men ikke stille diagnoser. Disse barna vil så bli viderehenvist til barne- og ungdomspsykiatrisk poliklinikk som vanligvis behandler barn på en poliklinikk og ikke ute i deres hverdagsverden som boken anbefaler. Det er på tide at det utarbeides norske retningslinjer for utredning og behandling inkludert tiltakskjeder for barn med selektiv mutisme. I påvente av dette, anbefales boken for alle fagpersoner som kommer i kontakt med disse barna og deres familier.

Publisert: 17. juni 2011. Tidsskr Nor Legeforen. DOI: 10.4045/tidsskr.11.0386

(C) Tidsskrift for Den norske legeforening 2023. Lastet ned fra tidsskriftet.no 26. april 2023. 